\title{
Catholics and Anticlericals
}

\author{
From Reforma to Revolution
}

Catholic partisans and revolutionary anticlericalists alike traced their struggle to La Reforma, a series of laws enacted by the governing liberals in the mid-I 800 s that restricted the scope of the Catholic Church. Conservatives responded with a war that they lost. Half a century later, La Reforma remained Mexico's “original sin" that attacked the nation's bond with God. ${ }^{\mathrm{I}}$ The failure to rescind the laws weighed on Catholic partisans after the revolution. Decades of complacency toward the La Reforma, they argued, had opened the way for the revolution's more forceful attack on religion. For revolutionaries, in contrast, enforcement of the Reforma laws had not gone far enough. The expansion of religious activities and the clergy's interference in politics proved that the state needed to restrict the church further to its proper, spiritual domain. Of course, decades had passed; new ideals and grievances animated both sides. Still, many revolutionaries considered themselves successors to the liberals just as many Catholics identified with the vanquished conservatives. For both, the clash in the I920s was the result of unresolved historical battles.

For the liberal politicians who sponsored the Reforma laws, the clergy's dominance in real estate, education, and politics exceeded its spiritual mission. The fledgling institutions of the government, the liberals reasoned, would become more effective once laws marked distinctions between civil and religious affairs. The liberal's closest model for governance was the United States. The separation of church and state, together

${ }^{\text {I }}$ Moreno Chávez, Devociones políticas, I35. 
with the system of checks and balances between the government's branches, charted a path away from the vestiges of colonialism and into republican modernity. La Reforma forced the church to auction off much of its land, eliminated ecclesiastic courts, and banned monastic orders. Birth, marriage, and death records became prerogatives of the state. Government officials now regulated bell ringing, sacramental fees, and religious activities beyond parish grounds. In the liberal view, the reforms were essential for democracy. The authority of civil institutions, which emanated from popular sovereignty, should prevail over the divine understandings of ecclesiastic authority.

For conservatives, La Reforma attacked the essence of the nation. They believed that only the authority of Catholicism could unify a country as diverse as Mexico. Without a vigorous church, the nation would splinter into chaos. The promulgation of the liberal Constitution of 1857 led to the Three Years' War (I857-60). After suffering defeat, conservatives allied with Napoleon III. The French emperor, eager to seize Mexico and its silver mines, sent troops in I86I. Together with local conservatives, the invading forces installed as Mexico's emperor the Austrian Archduke Maximilian of Hapsburg. For the conservatives, a foreign sovereign who was Catholic and noble was preferable to governance by liberals - or, even worse, annexation by Protestants. The United States, of course, had seized half of Mexico's territory. Liberals, anxious to resemble the neighboring country, seemed ready to surrender the rest.

When the empire fell in 1867 , President Benito Juárez ordered the execution of Maximilian and his Mexican generals, Miguel Miramón and Tomás Mejía. Conservatives faced imprisonment, expropriation of property, and exile. Defeated, the conservative party collapsed. Enactment of the liberal legislation altered relationships between the church, the government, and the citizenry. Nonetheless, Catholicism remained central. As a political force, Catholic opposition to the government became diffuse. ${ }^{2}$ Hard-line conservatives remained committed to recovering the Catholicism's influence, and sympathetic authorities often circumvented federal orders to expropriate properties. ${ }^{3}$

Although conflicts entrenched ideologies on both sides, partisans now favored newspapers, local elections, charity, and cultural events to war. Catholicism continued to shape understandings of citizenship, patriotism, and morality. Liberals hoped that the rational, subdued, individualist

2 Pani, Para mexicanizar el segundo imperio, 354.

${ }^{3}$ Moreno Chávez, Devociones políticas, I35. 
piety promoted by the church since the late eighteenth century would strengthen the republican ideals of individual rights, public order, and obedience to authorities. ${ }^{4}$

Tensions remained, but religious and political values came into greater alignment during the dictatorship of Porfirio Díaz (I 876-80, I884-I9I I). A liberal general, Díaz refused to rescind the Reforma laws. Still, Catholic partisans found much to like in his policies. Conservatives had long advocated for the centralized autocracy he forged. ${ }^{5}$ And religious activities found new openings. Bishops advised on economic projects and Díaz participated in public religious ceremonies. ${ }^{6}$ Many Catholics criticized the president's embrace of positivism (the philosophy that scientific empiricism would soon overtake religious superstition). But, of course, there was no single Catholic view. Positions shifted with varying political and ecclesiastical circumstances. A sagacious manipulator of rivalries, Díaz used this fluidity to stake his claim as the leader above the fray.

The broader Catholic context favored conciliation. After bruising conflicts with regimes in Italy, the Vatican urged Catholic groups to avoid "the vicissitudes of the liberal political system."” Instead, Pope Leo XIII's I89I encyclical Rerum Novarum called on Catholics to promote Christian solidarity. The wealthy were to look after the poor. Workers were to work hard, embrace sobriety, and eschew socialism. ${ }^{8}$ Upper- and middle-class parishioners responded with social programs that aimed to "strengthen the faith" and overcome poverty. 9 They promoted community-lending associations and labor unions, raised funds for hospitals, proposed land redistribution, and spread their message through a proliferation of Catholic newspapers. ${ }^{\text {To }}$ Díaz's lax enforcement of Reforma laws facilitated this approach. An I86I law had imposed government administration on religious charities. But Díaz encouraged private (mostly Catholic) philanthropy as the "most natural means to tend to

${ }^{4}$ Connaughton, Ideología y sociedad; Voekel, Alone before God.

5 Hale, "Emilio Rabasa"; Fowler and Morales, "Introducción."

${ }^{6}$ Menéndez Rodríguez, Iglesia y poder, 64-70; Ceballos Ramírez, "Rerum Novarum en México," I 5 I-70.

7 Andes, The Vatican and Catholic Activism, I3, I6; Cárdenas, "Un paréntesis reformista," 307-8; Hernández Vicencio, Revolución y constitución; Moreno Chávez, Devociones politicas, I35; Dumas, "El discurso de oposición."

${ }^{8}$ Olivera de Bonfil, Aspectos del conflicto religioso, 34-8.

9 Arrom, Volunteering for a Cause, 22.

ro Ceballos Ramírez, "La enciclica Rerum Novarum” and "Rerum Novarum en México." 
the pains and miseries of humanity." ${ }^{\text {II }}$ The later establishment of schools, hospitals, and orphanages widened the scope of the church, especially through lay organizations. ${ }^{\mathrm{I} 2}$ Indeed, the loss of its wealth and political power forced the clergy to rely on parishioners. ${ }^{\mathrm{I3}}$

Rerum Novarum encouraged male and female parishioners to apply their faith to public action. Within the new organizations, men became intellectuals, catechists, and administrators, while women provided individual care to orphans, the elderly, and families. ${ }^{\mathrm{I}}$ Despite limitations on their authority, women assumed new and more conspicuous roles. Indeed, ecclesiastical authorities encouraged women's maternal suasion "beyond the family circle." ${ }^{5}$ Barred from politics and business, upperclass women especially welcomed the opportunity to work along with the Society of Vincent de Paul, the Sisters of Charity, the Little Sisters of the Helpless Elderly (Hermanitas de los Ancianos Desamparados), and other charity organizations. The Reforma had done little to restrict this religious engagement in public. In fact, liberal legislation helped foster it.

Religious resurgence came on a wave of prosperity that helped create an urban middle class. The forced sale of ecclesiastical properties spurred real estate speculation. Subdivisions refashioned the capital with new colonias (neighborhoods outside the colonial grid). ${ }^{16}$ Liberals defined these developments as progress. The privatization of lands held by the church and indigenous communities would encourage capitalism and individualism. Just as railroads opened the countryside to mining and ranching, urban infrastructure cut into the bucolic peripheries of the capital. Agricultural lands, colonial-era country mansions, and shacks of indigenous laborers on the western edge of the city yielded to streets lined with single-family houses for the growing class of lawyers, bureaucrats, artisans, businessmen, teachers, and priests. ${ }^{17}$ Their professional status and piety combined to forge a new respectability that reflected the

${ }^{\text {II }}$ Arrom, Containing the Poor, 8-9; Secretaría de Gobernación, "Circular de Io de septiembre de I 885 ," quoted in Blum, Domestic, 9.

I2 Torres Septién, La educación privada en México, 60-6.

${ }^{13}$ Arrom, Volunteering for a Cause, 5; Bautista García, Las disyuntivas del Estado, 3I 5-I 6, 97.

${ }^{\mathrm{I}} 4$ Arrom, Volunteering for a Cause, II 4 , II 8.

15 Boylan, "Gendering the Faith," 202; Wright-Rios, Revolutions in Mexican Catholicism, 34 .

${ }^{16}$ Lear, Workers, Neighbors, and Citizens, 27-30.

17 Lear, Workers, Neighbors, and Citizens, I7; Morales, "Espacio, propiedad y órganos" and "La expansión de la ciudad de México," 76. 
triumphant fin-de-siècle luster. These were the imagined model citizens of the Mexico of Díaz: striving, urban, educated, virtuous, and charitable.

This spirit was pervasive in Santa María la Ribera, a new colonia west of the city center where many Catholic activists lived. Residents did not dig the trenches for the sewage system. Nor did they lay the stones in the plaza, install the gas lamps, or the lay the tracks for the streetcars. But these infrastructure improvements came from their tenacity before municipal bureaucrats. The fruits of their perseverance were scale models of the monumental projects in the city center. Díaz hired English engineers to drain the city's flood-prone lakes and Italian architects to design the Palace of Fine Arts and the majestic Post Office Palace (this was, after all, the City of Palaces). In Santa María, markets, theaters, and museums appeared around the Moorish-inspired bandstand, the kiosko morisco, that became the colonia's centerpiece after having served as Mexico's pavilion at the 1904 World Fair. ${ }^{18}$ The simple, elegant houses along the rectilinear streets, named after the cedar, orange, pear, and ash trees that grew along the San Cosme River, were tangible claims of superiority over the perceived filth in working-class neighborhoods. While most of the city's residents bathed once a week, and in public bathhouses, Santa María's homes were among the first to have separate bathrooms with tubs and toilets. ${ }^{19}$ San Cosme Avenue, marking the southern edge of Santa María, crossed Paseo de la Reforma and ran into the downtown park known as La Alameda. The Buenavista station, at the edge of the neighborhood, was the center of the national railroad network.

The religious institutions that moved into Santa María in the I 890 s added piety to the neighborhood's urbanity. The Jesuits established the Instituto Científico in the baroque colonial mansion known as La Casa de Mascarones; ${ }^{20}$ the school soon became the center of studies for local children of wealthy families. ${ }^{2 \mathrm{I}}$ Processions passed through Santa María from its two parishes, El Espíritu Santo and La Sagrada Familia, with streamers, fireworks, and brass bands. Priests such as José María Troncoso, director of the College of St. Joseph in Santa María, organized sacred music recitals for "true Catholic families" and encouraged parishioners to volunteer in hospitals, orphanages, and asylums for the elderly and the sick. ${ }^{22}$ Troncoso, who had criticized revolutionaries for their mistreatment of Catholics during the civil war, had founded the League

I8 Eineigel, "Distinction, Culture, and Politics," 77, 95.

I9 Agostoni, "Las delicias de la limpieza," 572. $\quad 20$ Torres Septién, La educación, 6I.

2 I Spenser, En combate, 3 I. $\quad{ }^{22}$ Moreno Chávez, Devociones, I02. 
of Catholic Workers, which sought to give voice to underpaid laborers while discouraging the drunkenness and other vices that supposedly kept them mired in poverty. ${ }^{23}$

Nearby, the Christian Brothers established the Colegio del Sagrado Corazón and the Marist teaching order founded the Colegio Francés de la Enseñanza Perpetua. Alumni of the Colegio Francés founded the Centro Unión. ${ }^{24}$ Mixing catechism, socializing, study, and athletics, the Centro Unión provided camaraderie and a haven from the city's sinfulness. Saturdays were for study circles while Sundays were for sports and catechism. ${ }^{25}$ The education that the Christian Brothers and the Marists provided was fundamental to the generation of young Catholics born at the turn of the century.

Both orders emerged in the wake of the French Revolution. In France, as in Mexico, the division between "revolutionaries" and "Catholics" was blurry and complex. Within the clergy, many supported republicanism over monarchy. Others feared that the assault on the established social distinctions known as estates would undermine the church's standing in France. Likewise, the importance of anticlericalism varied among revolutionary factions. Some revolutionaries destroyed parishes and smashed religious icons. Conservatives seized on incidents of anticlerical violence to support their vision that revolutionaries desired savage destruction. Horrified, the new teaching orders rushed to rebuild Catholicism's foundation by emphasizing the spiritual education of young men. Fearing that sedentary urban life was enervating congregations, leaving the church vulnerable to assaults, they encouraged vigorous piety through athleticism and military drills. ${ }^{26}$ The Christian Brothers' choice of names for their school, Sagrado Corazón, was significant. For French Catholics who fought against revolutionaries, the image of Christ's beaming sacred heart crowned in thorns was a banner of their devotion. ${ }^{27}$ Their arrival in Mexico proved timely.

The material comfort, piousness, and middle-class respectability that distinguished these neighborhoods in the capital contrasted with the social conditions endured by the working class and the peasantry. Many laborers lived in virtual slavery, remaining locked in shops until they

23 "Una importante personalidad," Mexico City, June 7, I925, Archivo General de la Nación, IPN, caja 228, exp. 33. On Troncoso's criticism of anticlerical revolutionaries, see Curley, "Transnational Subaltern Voices," I02-3.

${ }^{24}$ Torres Septién, La educación, 64, 66. $\quad{ }^{25}$ Barquín y Ruiz, Luis Segura Vilchis, I4-I6.

${ }^{26}$ Putney, Muscular Christianity; Klein, The Jesuits and Catholic Boybood, 3 I9.

27 Jonas, France and the Cult. 
worked off their debt. ${ }^{28}$ As much as they venerated Christ and the Virgin, they had little time and less money for the sacraments that marked the life stages of wealthier Mexicans. For many in the countryside, the expansion of railroads, ranches, agriculture, and mines encroached on local resources and autonomy. The dominance of foreigners in Mexico's bourgeoning agricultural and manufacturing sectors increased the sense of indignation. At the turn of the century, workers and peasants mobilized in protests that often ended in violent clashes.

In I9I0, after more than three decades in power, Porfirio Díaz was approaching eighty years old. To address labor strikes and village rebellions, his government turned to repression. His role as the nation's conciliator appeared to falter. A younger generation demanded reforms. Yielding to pressures, Díaz declared that the I9 I I presidential elections would be open to opposition parties. Francisco I. Madero founded the Anti-Reelectionist Party and campaigned before enthusiastic crowds. The stability and prosperity Díaz had brought to Mexico, Madero argued, had come at the cost of democracy and justice. Supporters appeared across the country.

Catholic partisans formed the National Catholic Party (PNC), which backed Madero. The PNC was small and, compared with other political associations, had little weight beyond its base in the state of Jalisco. But the formation of the party marked a shift from the post-Reforma reluctance to raise a confessional banner in politics. It was a complicated change. Madero came from a respectable Catholic family. However, he was a freethinking practitioner of Spiritism, the movement that sought to commune with spirits and apply science to the ethereal. ${ }^{29}$ Some of his advisors were anticlericalists. Under Díaz, the clergy had enjoyed amicable relations with the government. What would happen, the bishop of Guadalajara wondered, once the church "no longer depends on the tolerance and spirit of conciliatory supervision of the illustrious General Díaz" ${ }^{30}$ Still, the illustrious general was not long for this earth and support for Madero was widespread and effervescent. Compared with other opponents - the small, vocal group of anarchists, for instance Madero was a moderate. His proposed reforms to land and labor, elections, and rapprochement with the church echoed the Rerum Novarum

${ }^{28}$ Weis, Bakers and Basques, 62-73.

29 Brewster and Brewster, "Ethereal Allies," 93-I Io.

30 Mgr. J. de J. Ortiz, Archbishop of Guadalajara to Mora y del Río, Archbishop of Mexico City, 28 May г9ı r. Quoted in Meyer, The Cristero Rebellion, Io. 
spirit. The PNC's strategy, then, was a compromise. Rather than nominating a Catholic candidate to champion the church, the party supported a politician who shared some of their agenda. ${ }^{3 \mathrm{I}}$ Many came to regret the foray into politics.

As the elections approached, Díaz reneged on his pledge to allow fair elections. He had Madero thrown in jail and assumed the presidency again. Madero escaped from prison and fled to Texas, from where he called on Mexicans to rise in arms. Guerrilla forces following Emiliano Zapata, Pascual Orozco, and Pancho Villa soon wrested control of the countryside from the government forces. After a humiliating defeat in Ciudad Juárez, Díaz went into exile. After winning in new elections in October I9I I, Madero faced steep expectations. On the one hand, peasants and workers wanted Madero to return stolen land and defend labor rights. On the other, large landowners, businessmen, and conservative Catholics hoped that he could subdue these same peasants and workers. The new president disappointed people on both sides. Less than two years later, peasants led by Zapata revolted. Díaz's nephew took advantage of the turmoil to launch a conservative rebellion. Amid ten days of clashes in Mexico City, Madero's general Victoriano Huerta joined the rebellion, murdered the president, and declared himself dictator.

Reactions to the coup varied among Catholics. Rerum Novarum progressives and Maderistas in the PCN were horrified. Yet many conservative clergymen believed that Huerta's actions saved Mexico from greater destruction. The archbishop ordered a Te Deum, a ceremony that celebrated momentous events, in the Metropolitan Cathedral. It was not, he insisted, to celebrate the death of Madero but to thank God for the end of violence. ${ }^{32}$ Madero's followers were not convinced. They accused the clergy of further betrayal when they consecrated Mexico to the Sacred Heart of Jesus, the symbol of resistance against anticlericalism. Although preparations had begun during Madero's presidency, the ceremonies after the coup appeared to endorse Huerta's dictatorship. Sermons at the consecration strengthened this view. Church authorities bemoaned the "circumstances that now afflict the Mexican Republic." The circumstances they alluded to were not the coup and murder that had derailed Mexico's fragile democracy. Rather, bishops inveighed against the

${ }^{31}$ O’Dogherty Madrazo, De urnas y sotanas, 77-8I; Serrano Ortega, "Reconstrucción de un enfrentamiento," I7I; Curley, "Political Catholicism"; Correa, El Partido Católico Nacional; González Navarro, Cristeros y agraristas en Jalisco, vol. 2, 226-8.

${ }^{32}$ González Navarro, Cristeros y agraristas en Jalisco, 246. 
"atheism" unleashed by the Reforma laws that had eroded morality and invited chaos. ${ }^{33}$ Fusing religion with history and nationalism, these sermons pitted piety against the growing revolution.

Huerta's coup brought into the fray new revolutionary leaders from northwest Mexico. Zapata continued to fight in the south and Pancho Villa led forces in the northern state of Chihuahua. Now, Venustiano Carranza, a Díaz-era politician, succeeded Madero as the civilian leader. Álvaro Obregón and Plutarco Elías Calles commanded the military efforts of Carranza's Constitutionalist faction. For them, the struggle against Huerta meant combatting the church as well. Other revolutionaries remained committed Catholics. Madero had launched the struggle to oppose Porfirio Díaz, not the church. For Zapata's peasant soldiers, who tucked pictures of the Virgin Mary into their hats, Catholicism was a source of protection. Many Constitutionalists, though, were convinced of the clergy's complicity in the coup. Their support for Huerta revealed the true face of the clergy. Meddling priests were once again opposing the nation's progress, just as they had done during independence and La Reforma.

Catholic partisans countered that revolutionaries conjured images of a clerical cabal for political uses. Inspired by Protestants, socialists, and a hatred for Catholicism, anticlericalists had been waiting for the moment to attack. The chaos provoked by Huerta's coup and its aftermath provided the opportunity. At the head of the Constitutionalist faction's army, Obregón seemed to prove them right. Wherever his troops made inroads, they humiliated and terrorized the clergy. Stories of raped nuns, defiled churches, and executed priests circulated from mouth to mouth. They later appeared in newspapers and chronicles published abroad by a growing number of exiled Catholics. However plausible (no one questions whether violent acts occurred), these accounts impose a "formidable distance" between the events and the historian. They formed part of a partisan narrative that portrayed the clergy as "innocent victims" of revolutionary "barbarism." 34

Clergymen's opinions about Díaz, Madero, and Huerta were as diverse as revolutionaries' ideas about the church. Some priests supported the revolution; many revolutionaries saw the redemption of the downtrodden as their duty as Christians. Yet, as the conflict continued, nuance devolved into caricature. Grasping, lecherous priests appeared in speeches and

33 Butler, “La consagración," 33, 35.

34 Curley, “Transnational Subaltern Voices,” IOI-I I. 
newspapers with top-hatted capitalists and scheming politicians. In prochurch pamphlets, wild-eyed revolutionaries joined Caligula and Robespierre. The loudest Catholic voices condemned revolutionaries. The loudest revolutionary voices excoriated Catholicism. Each side fed the other in a vicious cycle of partisanship. Polarization undermined the possibility of collaboration between early revolutionaries and Rerum Novarum Catholics.

As revolutionaries vanquished Huerta's forces, they ordered the closure of religious institutions. In Santa María la Ribera, the closures were striking. Leaders of the interim government, Carranza and Obregón, closed the Colegio Francés in I9I4. ${ }^{35}$ Then, they seized the Saint Brigit parish and convent and turned it over to the anarchist organization the Casa del Obrero Mundial. The anarchists smashed the religious icons and made the church into a "rationalist school." The St. Joseph College became a "socialist center." Its former director, Father Troncoso, who had organized Catholic unions in Santa María la Ribera, fled. He joined hundreds of exiled clergymen in San Antonio, Texas. ${ }^{36}$ Revolutionaries seized the Casa de Mascarones, sending the Jesuits into hiding. ${ }^{37}$ Amid this convulsion, the wealthiest families moved out of Santa María. The city's growing population, fed by refugees from the countryside, outstripped public services. Displaced families slept in the kiosko. Streetlights failed, sewage pipes leaked, and garbage rotted in piles. Proud of Santa María's modern infrastructure, residents were dismayed at the scrappy settlements that revolutionaries set up for poor families nearby. These interlopers were a tiny part of what seemed to be a vast red wave crashing over Mexico, threatening the middle-class havens that had burgeoned during the years of Porfirio Díaz. ${ }^{38}$

For many capitalinos, the revolutionaries themselves were interlopers. Mexico City had plenty of local unrest, but the revolution was a provincial affair, an uprising of villagers. The ten days of fighting that ended in Madero's overthrow and rival factions' later occupation of the city led to famine and riots. The major battles, though, occurred in the countryside. None of the revolutionary caudillos was from the capital. Carranza, Obregón, and other leaders of the victorious Constitutionalist faction were all

35 Torres Septién, La educación, 66.

${ }^{36}$ Curley, "Transnational Subaltern Voices," I02-3; Olivera de Bonfil, Aspectos del conflicto religioso, 62. On Catholics fleeing to the United States, see Young, Mexican Exodus.

37 Torres Septién, La educación, 87. $\quad 3^{38}$ Eineigel, "Distinction," 93-6. 
from Coahuila, Sonora, Durango, and Chihuahua. These northern states excelled in mining, ranching, and agriculture, not in urban refinement. Once the war ended and the work of governing began, more northerners populated the new bureaucracies. These coarse revolutionaries trampled on the city's pious sophistication, and polite capitalinos regarded them with disdain.

The forced closure of the religious institutions in Santa María la Ribera and elsewhere was temporary. Many reopened after the war. However, the actions that followed institutionalized new restrictions on the church. Revolutionaries not only enforced existing laws that Díaz had overlooked, such as the prohibition on religious charities. They also gathered to hammer out an updated constitution. Most members of the constitutional assembly regarded themselves as successors to La Reforma. The name of the victorious Constitutionalist faction referred to the liberal Constitution of I 857. The assembly's task was to decide how to inject the ideals of the revolution into this now six-decade-old document.

This was not a simple task. Among the radicals, moderates, anticlericalists, and liberals, opinions varied over what the ideals of the revolution were and how to put them in place. After days of wrangling, the assembly agreed that the constitution should reform elections, land, and labor. The constitution of I9I7's ban on reelections aimed to prevent autocratic regimes like the government of Porfirio Díaz. Future presidents would serve only one four-year term. Article 27 addressed inequality in the countryside by authorizing the state to redistribute land "as the public interest may demand." Article I23 recognized workers' right to form unions and go on strike. It also established a minimum wage, eight-hour shifts, and paid vacations. Article 5 prohibited forced labor and payment regimes that kept workers in debt.

Rerum Novarum Catholic partisans could well have lauded these progressive accomplishments. Many had been advocating similar reforms for years. But new restrictions on the church were also centerpieces of the constitution. Revolutionaries argued that Porfirio Díaz's conciliatory approach had emboldened priests and bishops to flout civil law. La Reforma, they concluded, had not gone far enough to contain them. Now was the time to break Catholicism's exclusive domain and submit it to civil authority. ${ }^{39}$ Hence, the same laws that gave rights to workers and peasants imposed new restrictions on the church. Article

39 Diario de los debates del Congreso Constituyente, I9I6-I9I7, I, 54I-43. Quoted in Niemeyer, Revolution at Querétaro, 67, 77. 
27 authorized the government to transfer land from estates to villages. It also declared that church buildings and their contents - chalices, icons, paintings, and pews - were now property of the nation. The same logic of Article 5 applied to religious orders. The law that prohibited employers from locking workers in factories also barred convents and monasteries. Neither laborers nor nuns could submit to contracts that restricted their movement.

The state had new authority to restrict the clergy to spiritual matters. The church, as a body, could not engage the courts. Individual states determined the number of priests per capita. Priests had to register with local bureaucrats. Ecclesiastics and religious orders from other countries were prohibited. (As the archbishop pointed out, the law would have prevented Saint Peter himself from preaching in Mexico.) The constitution also banned religious political activity. Newspapers and political organizations whose titles or contents denoted confessional affiliation were illegal. Clergy could not vote or criticize laws. The constitution also barred the educational and charitable programs that were central to the Rerum Novarum resurgence. Education was to "combat ignorance, servitude, fanaticism, and prejudice" and promote "scientific progress," not religious dogma. ${ }^{40}$

As the first president to govern under the new constitution, Venustiano Carranza was a moderate. During the constitutional assembly, he opposed reforms that jeopardized private property. He also prevented extreme anticlerical measures that would have banned confession and forced priests to marry. After years of devastating war, his chief concern was to rebuild the government. In the three years after I9I 7 that remained of this term, Carranza pursued the new laws cautiously. His efforts to redistribute lands, enforce workers' rights, and confront the church were lukewarm. Nonetheless, the potential for more expansive reforms remained.

When Álvaro Obregón assumed the presidency in I920, he did not apply the anticlerical laws with complete vigor. The religious question was one of many matters to address. Procedures for national enforcement, in any case, had not been established. The consolidation of his authority was the most urgent task. His election had occurred amid deep fragmentation. When choosing a successor, outgoing president Carranza passed over Obregón, the most charismatic and popular of the revolutionary

$4^{\circ}$ Branch and Rowe, "The Mexican Constitution of I9I7"; Niemeyer, "Anticlericalism in the Mexican Constitutional Convention." 
caudillos, in favor of a civilian diplomat. Wary of Obregón's ambitions and eager to place a civilian in power, Carranza tried to isolate him and his supporters. Obregón loyalists accused Carranza of imposing arbitrary powers. They rose up and killed Carranza in the so-called Agua Prieta revolt.

Obregón triumphed in the next elections, but the violence called into question the legitimacy of his presidency. The constitution banned anyone from office who had "participated in a rebellion, mutiny, or military revolt." Agua Prieta suggested to Carranza supporters, and other opponents, that the Obregonistas had little use for Mexico's fledgling constitutional order. ${ }^{4 \mathrm{I}}$ This fragmentation among revolutionaries added another layer of political tension to the host of difficult tasks that confronted Obregón. Rushing to restrict the church would further compromise his political panorama.

Nonetheless, conflicts raged throughout the early I920s. Days after Obregón's inauguration, in January I92I, the church placed the first stones of a huge monument to Christ the King in the geographical center of the country. The event marked the anniversary of the consecration of Mexico to the Sacred Heart of Jesus (the ceremonies that revolutionaries associated with support for Huerta). When the Vatican's ambassador to Mexico, Monsignor Ernesto E. Felippi, attended the ceremony, Plutarco Elías Calles, then Obregón's interior secretary, had him deported.

The archbishop of Mexico, José Mora y del Río, was furious. The president further antagonized him by blaming the conflict on the "lack of sincerity of some high members of the clergy." Why, Obregón asked, did the clergy insist on forcing Mexicans to favor the church over the revolution? It was a false choice. Like Jesus, "the greatest socialist that Humanity has ever known," the revolution pursued the "tenets of true socialism." ${ }^{42}$ The revolution was not attacking the laws of God, as the clergy claimed; it was fulfilling them. By attempting to thwart the revolutionary reforms, it was the clergy who were opposing the teachings of Christ. Obregón's cheeky provocation preceded more concrete actions: in

${ }^{41}$ Estados Unidos Mexicanos, Constitución Política de los Estados Unidos Mexicanos, art. 82, frac. Vii. For a Carranza supporter's case against Obregón's election on this basis, see Islas Bravo, La sucesión presidencial, 21, 62. For the Catholic view, see "Piden se declare ilegal el registro de la candidatura del Señor Álvaro Obregón y nulos los votos que se emitan a su favor," September 2, I920, AHUNAM, MPV, caja 46, exp. 330.

42 Álvaro Obregón to Archbishop José Mora y del Río, Bishop Leopoldo Ruiz, and others, Mexico City, January 2I, I923. AHAM, Fondo Mora y del Río, caja I23, exp. 54. 
November I92I, for example, pro-Obregón workers bombed Mexico's most cherished religious site, the Basilica of Our Lady of Guadalupe.

Among the many Catholics who protested the Basilica bombing, groups of young men stood out. They belonged to the Mexican Catholic Youth Association (Asociación Católica de Juventud Mexicana, or ACJM). The ACJM had been founded in I9I4 by the French Jesuit Bernard Bergöen. A perceived "lack of apostolic zeal" among Mexican youth concerned Bergöen. He feared that, without solid grounding in religion, anticlerical revolutionaries might sweep up Mexico as they had France. ${ }^{43}$ Bringing young men closer to Christ would safeguard against such disasters. The ACJM combined athleticism and camaraderie with catechism. It followed the example of the YMCA (which established programs in Mexico in I909), though without the errors of the American Protestant group's teachings. ${ }^{44}$ After Huerta's defeat, Bergöen fled Mexico but returned to reestablish the ACJM in I9I7. Forged in the heated years between Madero's murder and the drafting of the new constitution, the group absorbed the sense that the church was under attack and that youth had to fortify religion with new spiritual commitment. Alumni of the Colegio Francés - the school in Santa María la Ribera closed by the interim revolutionary government - formed an energetic chapter in I9I9. They were a "select battalion." Together with the larger "army of Catholic Youth," they pledged to restore the Christian social order in Mexico. ${ }^{45}$ "As long as we are unwilling to die for Christ and give our blood for his love," one priest close to the ACJM declared after the Basilica bombing, "our society and our good works will languish." ${ }^{46}$ The importance of this ACJM chapter and its combative stance grew together with the conflicts that fractured the country.

Conflicts were recurrent, especially among revolutionaries. Presidential elections, as the Agua Prieta revolt had shown, were prone to violence. Without a transparent process of debate and selection, outgoing presidents nominated candidates. The nomination entailed more than moral support. It also brought government resources and national prominence. Passed-over revolutionaries with presidential ambitions could either accept impositions or revolt. Obregonistas had chosen to revolt against Carranza and won. At the end of his term, Obregón named Plutarco Elías Calles, his interior minister, as candidate and tensions flared again.

43 Aspe Armella, La formación social, 64. $\quad{ }^{44}$ Olivera de Bonfil, Aspectos, 50

45 Unión revista mensual, June I919. Quoted in Barquín y Ruiz, Luis Segura Vilchis, 20.

${ }^{46}$ Barquín y Ruiz, Luis Segura Vilchis, 47. 
Pancho Villa, who had negotiated his withdrawal from politics, intimated a return. He was gunned down soon after. Another contender was Adolfo de la Huerta, who had led the Agua Prieta revolt. De la Huerta had been active in revolutionary politics before the fall of Porfirio Díaz. After joining Madero in the early days of the revolution, he went on to serve in distinguished positions in the government, including finance minister under Obregón. His skills of diplomacy had been vital for negotiations with rival revolutionaries and the United States. He enjoyed broad support from military leaders, which emboldened him to revolt. Crippled by internal divisions, the rebellion failed, and De la Huerta fled into exile.

Once in the presidency, Calles hastened to establish the primacy of the federal executive. Stability, of course, required shoring up the loyalty of local officials and the military. The long-term goal of forging a new revolutionary society, though, relied on two broader conditions. First, the government needed to enforce the laws it passed. Second, it had to expand its reach beyond the limited sphere of politics, into aspects of everyday life that were most meaningful to ordinary Mexicans. These conditions went hand-in-hand. The constitution granted the government authority over land, labor, health, and education. Yet, until officials determined how to enforce them, the constitutional articles expressed mere ideals and aspirations. Calles made the articles enforceable by inserting them the penal code. In one stroke, he approached both of the broad conditions. The government's incursion into areas long dominated by religious organizations was now a matter of rule of law. The ensuing clash was systemic. Institutions and laws, not sporadic bombings and incendiary rhetoric, intensified the antagonism.

According to the new penal code, punishment for infringement of anticlerical laws included fines, jail sentences, deportation, and exile. The maximum number of priests was now one for every 10,000 in the populous central states and one for every 3,000 inhabitants in frontier and costal states. To ensure this ratio, priests had to register with municipal authorities. The government ordered religiously oriented hospitals, orphanages, schools, and asylums to remove crucifixes, prayer rooms, and any other vestiges of religion. School calendars replaced Catholic feast days with patriotic commemorations that illustrated the triumphant journey from independence to La Reforma to victory over Maximilian and to the revolution. ${ }^{47}$ Small armies of hygienists, engineers, eugenicists,

47 Vaughan, The State, Education, and Social Class, I75-6. 
and physicians launched public welfare campaigns. The competition between government and church programs has led scholars to argue that this was rivalry of similar values, not a clash over incompatible ones. ${ }^{48}$ But these public welfare programs pursued more than tending to the needy. They aimed to reconfigure the relationship between families and society and shift citizens' loyalty from the church to the state. No longer about charity and piousness, welfare was a matter of state formation.

Horrified by the socialist ideals that inspired these reforms, conservatives within the clergy reminded Mexicans of their duties to God. The nation sprang from divine will, not from spurious laws drafted by men. Catholics had an "individual and social obligation to worship God." Any law that upended this bond violated "sacred moral values." 49 The Archbishop refused to "obey laws that were contrary to the rules of the Church." ${ }^{\circ}$ Catholics were ready to face the consequences. "We place our cause in the hands of God," he wrote to Calles. "If He wants to allow us to suffer, we shall suffer happily, certain that this very suffering will bring closer the day in which His rights will be recognized and His church respected." ${ }^{\mathrm{I}}$ For Calles, this loyalty to the church over the government to divine law over civil law - was tantamount to rebellion.

Therefore, Calles supported the establishment of a new church that appeared in early 1925 as a nationalist, revolutionary alternative to Roman Catholicism. Founded Joaquín Pérez, a former priest, the Mexican Catholic and Apostolic Church (Iglesia Católica Apostólica Mexicana) proposed to purge Christianity of papal corruption. As its motto declared, this was to be a "Mexican Church for Mexican priests." Liberated from ties to the Vatican, the new congregation aimed to decolonialize Mexican spirituality. Proclaimed the patriarch of the new faith, Pérez attracted a modest following of priests and congregants, but for Roman Catholic activists his movement was nothing more than a heretical affront to religion and a testament to the government's hypocrisy. Precisely when the Catholic leaders felt compelled to shutter parishes, the government turned over to Pérez the venerated churches La Soledad and later Corpus Christi. At the Mexican Church's debut, Catholics routed the interlopers with sticks and fists. In the following

${ }^{48}$ Hanson, "The Day of Ideals"; Andes, "A Catholic Alternative to Revolution."

49 "Carta pastoral del Episcopado de nuestro país," Excélsior, July 25, I926.

50 "Los colegios católicos de México no serán vendidos, declara el Sr. Arzobispo," Excélsior, July 20, 1926.

${ }^{5}$ José Mora y del Río to Plutarco Elías Calles, Mexico City, June 3, I926, AHAM, Fondo Mora y del Río, caja I23, exp. 53. 
days, police and firemen had to protect priests and followers of the new church from riots. ${ }^{52}$

The official support for the patriarch Pérez further confirmed the conviction that Calles sought to destroy Roman Catholicism. The president certainly aimed to weaken the authority of the church. Yet his efforts were as much about strengthening the power of the state as they were about religion. Hence, he was not entirely disingenuous when he claimed that the anticlerical campaign was not antireligious nor even anti-Catholic. ${ }^{53} \mathrm{He}$ warned church authorities that "The only way for you to avoid problems for yourselves and the government is to submit to the mandate of the law. Let me stress to you, once and for all, that any act of rebellion ... will be punished." ${ }^{54}$ This rhetoric applied to priests as much as to the disgruntled revolutionaries. The law was the tool of statecraft, the instrument with which the government of the revolution was going to refashion Mexico.

Calles understood his actions as the fulfillment of La Reforma. His liberal predecessors had sought to remove the Catholic Church's colonial-era privileges. They understood that the vast majority of Mexicans were Catholic. Yet, for them, the church's exclusive tribunals, its "dead hand" administration of real estate and its monopoly on the nation's moral education were incompatible with the modern republic. The Reforma laws attempted to restrict the church to matters of the soul. They secularized charitable institutions, forced the sale of ecclesiastical properties, and asserted civil authority over sacramental fees. Erected and legitimized by representative democracy (in theory at least), government institutions would now oversee the life stages, education, and well-being of citizens.

Far from spawning republican ideals, however, La Reforma threw Mexico back into the instability and violence that had roiled the nation since independence. By the turn of the century, the political leadership and the church reached a compromise of sorts. Díaz, the former liberal general, recognized the church's moral authority as a salve for Mexico's economic and social vicissitudes. While never rescinding the Reforma laws, he enforced aspects of them laxly. Members of the church, in turn, adapted their beliefs and practices to the changing times. The clergy remained formally banned from engagement in public life. This limitation

52 Butler, "Sotanas Rojinegras"; Ramírez Rancaño, La patriarca Pérez.

53 Blancarte, "Laicidad y laicismo," I 40.

54 Plutarco Elías Calles to José Mora y del Río, Mexico City, June 2, I926, AHAM, Fondo Mora y del Río, caja I23, exp. 53. 
pushed parishioners to assume new responsibilities. The resulting lay associations inspired by the Rerum Novarum did not circumvent the Reforma laws; rather, they accommodated their religious beliefs and practices to ascendant liberalism. The new middle- and upper-class colonias that emerged in Mexico incorporated this religious and social ethos. As markers of turn-of-the-century piousness, respectability, and modernity, parochial schools and lay charities were as important the public parks, ornate gas lamps, and private bathtubs.

For many revolutionaries, this pious respectability concealed the old guard's recalcitrance before the upheaval of the masses. The resurgence of religious activity under Díaz was evidence of the church's creeping reencroachment on the public sphere. By allowing the church to recover lost terrain, Díaz had betrayed the liberalism that he defended in the face of French intervention. By perpetuating himself in power for three decades, Díaz also violated the democratic promise of liberalism. Within his dictatorship, the clergy found accommodation. In this view, ecclesiastics confirmed their authoritarian sympathies by celebrating the toppling and murder of Madero. Bishops, priests, and nuns believed themselves to be above the modern rule of law, anticlericalists argued. They also opposed the vindication of the poor masses that the revolution represented.

The legislation that revolutionaries drafted in the constitution of I9I7 would compensate for La Reforma's evident deficiencies. It gave more authority to civil institutions. It barred Catholics from manifesting their religious beliefs through charity, education, journalism, and politics. The emerging revolutionary order upended the Rerum Novarum generation, the members of which turned to resistance. 